\title{
Political control and journalist protests in Spanish public media in electoral campaigns: A decade of conflict
}

\section{Carme Ferré-Pavia}

Media, Communication and Culture Department, Communication Faculty, Autonomous University of Barcelona, Carme.Ferre@uab.cat

DOI: http://dx.doi.org/10.5324/eip.v12i1.2239

(cc)BY
Attribution 4.0 International License, which permits unrestricted use, distribution, and
reproduction in any medium, provided the original author and source are credited.

For thirteen consecutive years, Catalan public broadcasting journalists have protested against the so-called coverage quotas established by Spanish electoral regulations. According to those regulations, during election campaigns, broadcasters are required to use a calculated number related to the proportion of votes cast in the previous election to determine the amount of broadcast time they allot to each party. Journalists have repeatedly and publicly complained about the quotas, while simultaneously explaining the effects of the quotas to the audience and not crediting authorship of this news. This paper undertakes an in-depth analysis of the case and its historical roots from different angles: the protests, the journalists' professional roles, the political parties' strategies, the roles of the regulatory boards and the initiatives taken by some professional organizations and institutions. The theoretical framework focuses on the mistrust between the political class and journalists in the context of a mediatized conflict with ethical implications. The methodology includes extensive document examination, news content analysis and interviews. The results indicate that the Spanish political class has deemed the performance of the Catalan public broadcaster as tending to equate political information with electoral spots controlled by parties. The consequence of this has been an enduring conflict between politicians and Catalan journalists that distances citizens from both of them.

Keywords: Spanish public media, media conflict, journalistic-political conflict, politics and ethics in media.

\section{Introduction}

For the first time in thirteen years of protests, some Catalan public broadcasting channels ${ }^{1}$ tested the action of not implementing the blocks system in the campaign for the 26 June 2016 general election ${ }^{2}$. The measure was very discreet, but television analysts noted that "the informative services of TV3 [Catalonia Television] have achieved something with this action" (Planas 2016, my translation). In May 2016, the Catalan Journalists' Association (Catalonia is an autonomous region of Spain which has its own institutions) announced that actions against what it considers to 
be the political control of public media would continue ${ }^{3}$. One year earlier, they had submitted a request to the European Court of Human Rights to denounce the socalled electoral blocks (quotas) in Spanish public media. The blocks are timecontrolled pieces of news reporting on political parties' daily agenda during electoral campaigns during the fifteen days before elections. It is a system that requires journalists to adjust the length and order of news coverage to the parties' parliamentary representation rather than news values.

For thirteen consecutive years, Catalan journalists have been denouncing these limitations, which are regulated by Spanish electoral boards. Catalan media professionals refused to credit their news pieces (in a move similar to a by-line strike in the press, known as a "signature strike" or "vaga de signatures" in Catalan) or even appear on air due to the protests. Likewise, journalists of the Spanish public broadcasting corporation (Televisión Española) requested the removal of the coverage quotas in May 2015. In July 2015, the European Court of Human Rights in Strasbourg rejected the Catalan demand and the professional protests continue (EFE 2015).

This paper examines the roots of the political and media conflict, which involves the ethical decisions of both groups, journalists and politicians, in the sense that the former do not assume responsibility for the information broadcast and the latter apply political control over that information. The objectives are threefold: first, to analyse how the protests have been carried out; second, to look at the stands that political parties and journalists have taken; and third, to examine the role played by the institutions involved.

The issue seems to be more complicated than one may at first expect, since some academics and sources defend the convenience of coverage quotas as a minimum guarantee of media pluralism (Zabaleta 2000, Ferrer 2007), reflecting citizens' lack of trust towards the journalists who participated in the "signature strike". More indulgent views state that those protests may be considered an almost customary element in any electoral campaign (Tomàs 2007), while more contentious ones talk about the protests as "stupidizing" journalism.

Since 2011, private media bodies have also been bound by the same rules of electoral coverage (García and Rallo 2013) but they do not follow them; only public news organizations comply with the regulations. From a theoretical point of view, this conflict focuses on the mistrust between journalists and politicians in an ethical and practical case in a modern European democracy. This mistrust has been demonstrated frequently in studies in different countries and contexts (Brants, De Vreese, Möller and Van Praag 2010, Rawsley and Gong 2011). Van Dalen, Albæk and De Vreese (2011) confirm that, compared to their colleagues in Northern Europe, Spanish journalists have the most cynical view of politicians, which they partly explain by feelings of political pressure.

Until today, academic research has paid little attention to the Spanish electoral blocks, even though they are considered "an exception in Europe" (Almiron, Capurro and Santcovsky 2010a); few references have been made to academic research and none in an international forum.

The overall situation of political control over the media has been analysed in the context of political systems. Spain, like Italy and France, corresponds to the Mediterranean model, which is defined as being less professionalized and seeing greater instrumentalization of the media by political parties (Almiron, Capurro and 
Santcovsky 2010b). As Gnisci, Van Dalen and Di Conza explain, the polarized pluralist media system is "characterized by lower professionalization, strong connection with political power and strong state intervention" (2014: 125).

\section{Media ethics in political campaigns}

It is assumed that media ethics cannot be mandated by government if the press is to be truly free in democratic societies. In most countries, the journalistic profession is a self-regulated field, in which observation, interpretation and evaluation are considered to be journalism's civic functions (Borden 2007).

Nevertheless, in those political regimes the informative agenda is often influenced by political parties, economic groups and supranational policies. Merrill (1989) defends reconciliation between freedom as professional journalists' raison d'être, engagement with society, and personal responsibility over institutional commitments and relationships with elite groups. Some authors even stress that democracy should promote more open media by avoiding biased news and identification with particular politicians (Porto 2007).

In electoral periods, the media have an even greater responsibility to the masses in their reporting of political campaigns. Historically, the media have had an evolving role as an instrument of political processes (Ramdsen 1996, Kaquali and Esipisu 2009) and are scrutinized the most closely, especially the public media organizations. Mistrust of the media in electoral coverage has inspired many studies focused on media bias, such as those in the United States that discuss Republican and Democratic support in television and internet news and photographs (Lee 2005, Lowry 2008, Baum and Groeling 2009, Grabe and Bucy 2009, Hehman, Graber, Hoffman and Gaertner, 2012). Citizens also question the media's political balance, which is perhaps a sign of contemporary times:

Faith in the fairness and accuracy of the news media has also dropped precipitously among regular citizens. According to Pew (2011), whereas a clear majority (55\%) of Americans trusted the news media to "get their facts straight" in 1985, only one in four Americans feel the same way now. Similarly, in 1985, 34\% of Americans trusted news organizations to deal fairly with all sides in "presenting the news dealing with political and social issues", but less than half that percentage (16\%) trusted them to do the same in 2011. According to the same July 2011 poll, nearly two-thirds of respondents agreed that news organizations were "politically biased in their reporting" (versus 45\% in 1985) (Groeling 2013: 131).

Those data contradict in part the concern about media influence on voters, which in early 2000 was an important focus of research. For example, Fox, Angelini and Globe (2005) have demonstrated the heavy media reliance of late deciders watching television in their studies about media bias:

During the final weeks of a campaign a substantial number of voters - often enough to swing an election - have not yet made up their minds as to which candidate they will select. These voters are looking to television news for information to help make informed choices. But the information broadcast to the public in the final weeks of the campaigns emphasized hype rather than substance (2005: 104). 
In recent years, the focus has shifted to the so-called prosumers: readers and consumers that produce content and participate in the social media and internet spaces of the traditional media. The main aspects have been bloggers' lack of ethics, especially on delicate issues such as health (Hsin-Hsuan, Van Dolen and Kolk 2013) and voting (Bermúdez 2012, Greenland 2013, Henderson 2013). Research specifically about online newspaper comments and participation on Twitter (FerréPavia 2014) has revealed a lack of ethical commitment with respect to migrants and the massive use of Twitter in social demonstrations in Spain to express emotion but not to inform or mobilize.

\section{Trust and dialogue in media messages}

Journalists' and the media's ethical principles of independence and social responsibility were set out in the declaration by the Commission on Freedom of the Press (1947), which stated that the press should remain free from governmental or corporative pressures in order to serve society. That set of principles is also considered fundamental by Cooper (1989) and Lambeth (1986) in their proposals for the categorization of the universal principles of journalistic ethics (Rodríguez, Figueras, Mauri and Alsius 2013). Considering global media ethics, some authors have defined the three universals, or values, as "a) the quest for truth; b) the desire for responsibility; and c) a compulsion for free expression" (Cooper and College 1990: 5).

At the intersection between media ethics and political communication lie the power of media and their message on creating trust in people and institutions (Gross, Aday and Brewer 2004), and the extent of the media's impact on people's participation. It has been a constant debate in communication studies in the last 30 years and is emerging once again in the digital age (Ceron 2015).

Some authors have not found a correlation between trust and participation (Shah 1998, Uslaner 1998). Others offer data from empirical studies in specific contexts that affirm the opposite: "Experimental Studies in the Netherlands (De Vreese 2005), Denmark (De Vreese and Elenbaas 2008, Elenbaas and De Vreese 2008), and Sweden (Shehata 2014) have shown that exposure to strategically framed campaign coverage increases political cynicism" (Ariely 2013: 441).

Trust is related to people's assessment of competence, honesty and capacity to be trusted. Studies done in the USA and Europe confirm that trust has diminished not only in media, but also in governments (Chanley, Rudolph and Rhan 2000, Kepplinguer 2000). Contextual factors become crucial to understanding the effects of electoral campaigns on political engagement and cynicism (Schuck, Boomgaarden and De Vreese 2013).

To understand the methodological difficulties of studying the link between media and political trust, it is necessary to determine whether or not attacks on interpersonal and inter-group trust can lead to alienation from political life.

As demonstrated in various ways, perceptions of the media are linked to perceptions of government. Their fortune has declined together. This could represent the decay of something more fundamental that affects people's general trust in society, but it also might represent the mutual destruction of government officials and the media. As they attack and criticize each other, 
they pull down evaluations of themselves and related societal institutions" (Bennet, Rhine, Flickinger and Bennet 1999: 17).

Other researchers suggest that personal attacks, rather than bad news, are responsible for undermining trust (Min 2004), because trust in institutions depends on the trust we place in people:

Analysis of the many empirical studies shows that, although media usage generally stimulates political participation, it is less clear when negative news will nullify this effect. Negative news may have not only short-term behavioural effects, but also effects on underlying attitudes such as trust in politicians, which may bare a sleeper effect on political behaviour only in the long term (Kleinnijenshuis, Van Hoof and Oegema 2006: 101).

Empirical research observing how electoral blocks were received in the Catalan elections in 2010 has shown that the blocks produced disengagement. In a study that made daily observations of a group of 22 people who consume these kinds of news pieces, mutual attacks between politicians emerged as the second cause for avoiding watching television during the block (Carrillo 2012). The electoral quotas are a concrete problem compared with the global one of the spectacularization of politics (Carrillo and Ferré-Pavia 2013, Ferré-Pavia 2013).

Various authors assign the media responsibility for having an effect on participation that may be positive or negative, but rarely neutral. For many researchers, demobilization is connected to a lack of trust that reaches both individuals and institutions, and affects the media as institutions (Uslaner 1999); there is debate as to whether or not less trust leads to less participation (Ansolabehere and Iyengar 1995, Jeffres, Atkin and Neuendorf 2002). Considering the media as another social actor, the battle between the media and institutions can distance people from both at the same time.

\section{Methodological design for an ethical conflict}

This paper will examine the roots of this political and media conflict: first, by analysing how the protests have been carried out; and second, by looking at the role played by the political parties, journalists and institutions involved. The study focuses on contextual elements in the Catalan case to assess the way in which the journalists' protests have evolved from their origins, and to observe how the institutions involved (such as political parties, electoral boards, broadcasting boards) have kept the conflict alive for thirteen years.

In terms of objectives, the methodological tools applied are content analysis and interviews. News pieces from several electoral media campaigns and institutional documents comprise the content analysis samples. 5 . The research method is historical and includes archives and interviews with people who were involved. The chronology of the documented protests includes the five first years (2003-2007), which is the period that is most difficult to remember nowadays, and five campaigns, including local, regional, national and European elections ${ }^{6}$.

For the news content analysis, the media studied are the public organizations Televisió de Catalunya (television channel) and Catalunya Ràdio (radio station). For each campaign, a different daily TV or radio news show was chosen for the central days of the campaign to compare how the protest developed. 
The documental archives reviewed concern regulatory authorities, professional associations, electoral boards and the Catalan ombudsman ${ }^{7}$. In the case of the interviews, nine in-depth interviews were carried out with members of electoral boards, news editors and representatives of professional associations and the regulatory boards that were in charge in that period. The one exception was the interview with a news editor who is now an activist against the blocks ${ }^{8}$. All of them made decisions on the protests or on the electoral control of news timing.

The data collected are complete which makes it possible to properly establish the actors' positions and how they carried out the protest. Such a detailed review (documents, professional protest and statements) involved limiting the period to the years studied, bearing in mind that the protest continues today.

It is possible to find some studies that analyse journalists' strikes, for example how citizens' identify with newspaper strikes (Moy, McCoy, Spratt and McCluskey 2003) and different protests in North America (Demers 2006, Neilson 2012, Cohen 2014), but none of them is involved with protests against electoral laws.

\section{Results}

This section uses a narrative approach to describe the results according to the three established objectives. This approach was chosen to make it easier for readers to understand the conflict - between a control on pluralism and journalistic ethics and freedom - in context.

\section{The "signature strike"}

The protests started in 2003, when a request by the Catalan Journalists' Association (CJA) to eliminate the blocks was ignored. In summer 1999, the CJA sent out a document entitled For a new public broadcasting model, which stated':

It is necessary to have media that guarantee information that is plural, independent and designed to satisfy citizens' interests before any others. Secondly, public media are necessary to guarantee that the whole population has access to radio and television services. Thirdly, they are also necessary to guarantee the existence of public spaces that can transmit to people an awareness that they are part of a collective group.

On 28 May 2003, the CJA issued another document on 8 September 2003, For a reform of public media, which insisted on its previous demands. The document does not refer to the electoral blocks, but it does suggest that the boards of administration of public media should be more professional and less political. This has always been the underlying debate: freedom versus political control of those working in public media.

On 29 October 2003, shortly before the Catalan Parliament elections called for 16 November, the professional committees presented a manifesto against electoral blocks ${ }^{10}$. The text referred to the CJA document and stressed that the blocks were an "unknown phenomenon in Europe" and a "journalistic aberration" that had been the only possible consensus among political parties due to "their mutual lack of trust".

According to Pilar Antillach, president of the CJA's Public Media Committee at that time, TV3's coverage of the 2003 local campaign, when the reporting of a 
terrorist attack in Casablanca (Morocco) was "hidden" by the electoral blocks and minimized in news bulletins, set things in motion.

On 7 November 2003, a protest to avoid crediting news pieces (part of the "signature strike") was put into practice. On Catalunya Ràdio reporters read a statement explaining the reasons for the "signature strike". In that evening's news bulletin, journalists working on the election did not put their name to the blocks and they did not appear on air. The other pieces revealed the identity of their authors, but no special explanation of the reasons for the protest was given to the audience. ${ }^{11}$

In the following days, news pieces were credited to journalists, but on the television news programme La nit al dia (10 November), a special statement about the protest was made before the blocks: "Our colleagues are following candidates in real time and will explain their proposals according to the order agreed to by the political parties".

The protest must have had an effect, because for the Spanish Parliament elections held on 14 March 2004, the board of administration of the Catalan public broadcaster discarded the blocks and agreed to increase the coverage devoted to the smallest political parties. That campaign abruptly ended with the 11-M train attacks $^{12}$.

Mònica Terribas, at that time editor of the TV3 midnight news show La nit al dia, reported, "Don't expect journalism in the coverage of the main political parties in the general elections: the political parties will have time slots for political propaganda, in which they will only focus on what is allowed. This situation will lead to a subtle denial of press freedom" (Terribas 2004: 78).

The Spanish Electoral Board accepted the complaint forwarded to it by the political party Convergència i Unió and the quotas were reinstated.

The home rule (Estatut d'Autonomia) referendum followed what was becoming the norm in every campaign. In 2006, the protests had been going on for three years, and the referendum gave them more visibility. On 6 June 2006, the Spanish Electoral Board overrode the former agreement of the Barcelona Electoral Board and revoked the criteria adopted by Catalan public media regarding a more flexible order of appearance in the blocks. This time the Socialist Party submitted the appeal.

From this moment on, the protests became more conclusive. On the noon news show, TN Migdia, on 9 June, the presenter read the following statement:

Today you will notice that not only are news pieces about the referendum not 'signed' by journalists, but the entire news bulletin has not been credited. This is TV3 staff's protest against the rule determining the overall length of these news pieces according to the political representativeness of the party in question.

On the evening news show, TN Vespre, on 11 June, nothing was said at the beginning, but in the middle of the summary of the campaign activities, the presenter stated:

The following news story, as well as those on the rest of the campaign, has not been 'signed' by the journalists. This is a protest action taken by TV3 staff due to the rule that sets the order and the length of these news stories according to their political representation. 
The late news show, La nit al dia, on 14 June, reiterated their message:

We remind you, once again, that this summary news piece that we do every day has not been 'signed' by our colleagues, who are protesting due to the criteria established by the Catalan Broadcasting Corporation that establish airtime limits for our work.

TV3 repeated the protest in different ways and at different times during news bulletins. The campaign news section did not claim authorship during the whole campaign and on some days no credits were provided for the whole news bulletin. At the end of the evening news show on 20 October, the presenter said:

This and the other news pieces you have watched in this programme were not 'signed'. This is a protest by the TV3 newsroom against the regulations that set the time and order of campaign news pieces according to political parties' parliamentary representation and not according to newsworthiness criteria.

According to a report by the Catalan Broadcasting Council, TV3 continued to give more airtime to the strike than to other related political issues.

The last campaign analysed in this study - for the local elections on 27 May 2007 - repeated the protests, which were beginning to cause discontent, or at least some criticism, among audiences. On TV3, TN Migdia on 18 May did not include any statements about the protest, but no news pieces attributed authorship throughout the entire news bulletin.

On La nit al dia on 23 May the following statement was read after an interview:

Political information is determined by airtime time ranges that impair our work. We also believe that, ultimately, these time ranges impair citizens' right to have political issues reported in a less restricted way in these kinds of campaigns. That is why the newsroom is protesting and refuses to put its name to news pieces at this time.

\section{Attitude of professionals}

The journalists' opinion is that the control imposed by the blocks goes against television parameters. In one of the interviews, Arderius says that the boredom and distance created by political parties contribute to losing viewers rather than gaining them: "The message is not getting to people. We have to think about TV formats that allow for greater flexibility".

Rosa Marqueta, TV3's editor-in-chief, and Manel Raya, deputy editor-in-chief and the person in charge of electoral campaign teams at that time, believe that the conflict has stalled: "Negotiations have been tried, with no results. There is no political will". Like other journalists, they believe that if the Catalan Broadcasting Council mediates the conflict throughout the year, the special conditions for the campaign coverage become an unacceptable exception.

According to Pilar Antillach, former president of the Public Media Committee of the CJA, the problem is that "the [electoral] campaign is permanent". The professional regulation has become a form of "control" that is already convenient for some professionals, because they do not have to take editorial decisions. Antillach says editors complain that 40,000 to 50,000 viewers are lost during the 
block sections. She agrees with Arderius that such blocks generate "apathy", not only in the audience but also among journalists and politicians.

In Antillach's opinion, there is also room for self-criticism: "The electoral blocks and the professional protests are an inter-professional issue; the private media trivialized it, we were not self-critical and we did not explain it well". Unanimity is difficult to achieve because of sectarianism and the "perverse" collaboration of politicians and journalists, she says. Josep Carles Rius, head of the CJA during those years, also points out a lack of unanimity among journalists.

\section{Political parties apply quotas}

The CJA requested that political parties refrain from taking any further action against the agreements to start loosening the quota system. It is important to thoroughly analyse the role of political parties concerning the journalists' attempts to clearly separate electoral advertisements from daily news in the public media.

As seen above, both the Socialist Party and Convergència i Unió (CiU) appealed to different electoral boards due to their disagreement with decisions made by the boards of some public channels that aimed to loosen the blocks.

The leftist party Iniciativa per Catalunya (ICV) and the separatist force Esquerra Republicana de Catalunya (ERC) went along with the CJA during the presentation of the manifesto against the blocks in 2003. ERC stated that it would oppose the blocks and "make them disappear". In 2004, the Socialists criticized CiU's appeal and confirmed the "party's commitment to a review" of the blocks. In 2006, however, it was the Socialists who appealed.

The last appeal in the period analysed was brought by $\mathrm{CiU}$ and resulted in changes to the criteria of the electoral boards, which had been remarkably unstable and in flux (Montero, 2015). The Barcelona Electoral Board's response to CiU, later ratified by the Spanish Electoral Board, separated the electoral blocks from newsworthiness criteria and stated that the electoral boards' role was not to set the channels' daily schedules.

Freedom of programming must be respected and the public administration does not have the power to limit the length of news programmes or to enforce campaign activities being covered in them. [...] With the exception of free airtime for electoral propaganda, the Electoral Boards cannot intervene in the programming of the broadcast media, as long as the principles of political and social pluralism and the neutrality of the public media during the electoral period are respected.

\section{Battle between professional associations}

Josep Carles Rius, head of the CJA in 2007, pointed out that no shared position had been adopted despite the will to do so. The disagreement was founded on whether or not self-regulation should be defended. For some journalists, the requested equality could be considered only a euphemism as long as political parties controlled the boards of the public channels. A press release by the CJA on 9 May 2007 made this lack of convergence clear:

We deplore the fact that the criteria of neutrality, equality, plurality and balance that must be part of an advanced democracy are being misinterpreted 
and wrongly implemented through the system of blocks and pre-determined time and order allotment in the public media. These criteria ignore informative interests and the most basic professional principles of journalism. These principles should not be foreign to self-proclaimed independent private media either.

The CJA ordered a report about the nature of the blocks from the lawyers Josep Mir, Carles Pareja and Gemma Segura. The conclusions, issued in May 2007, stressed some of the common issues regarding this controlled content:

- The blocks do not correspond to the public interest.

- The imposition of edited TV broadcasts (given by the parties) denies people their right to information.

- The blocks turn journalists into mere transmitters.

- The blocks make information equivalent to propaganda because both are administered in the same way.

- There is no legal stipulation for the imposition of the blocks, and they infringe on constitutional rights.

- The distribution of information in blocks does not guarantee neutrality. It is instead the content of the information that has to be neutral.

- Regulatory mechanisms for pluralism already exist: the inclusion of political parties in the management of public media, the presence of parties in the daily programming schedules, and the establishment of rules for free electoral propaganda during campaigns.

The Journalists' Union, for its part, has always opposed the quotas. In May 2006, it was cautious about the more flexible agreements achieved, but voiced its opposition to politicized media management:

It will no longer be obligatory to measure the minutes of each news piece every day, nor will the order have to be determined according to electoral representativeness. Nevertheless, in the global estimates of the campaign, requiring some percentages to be obtained for electoral influence remains unquestioned, as does the assumption that pluralism translates more or less strictly into proportionality. To achieve more freedom, a board is needed whose sole aim is not to represent the interests of the parties. The managers of Catalan public media who have defended criteria of independence and informative neutrality do not need to be overseen by political representatives, who are sometimes the same people who are in charge of the corresponding electoral campaign."

Their Outcomes of the mobilization against the electoral blocks on 5 June 2007, when a new era supposedly began, stated:

We believe that a new perspective of progress in the professional struggle against electoral blocks has begun. Given the strength of our last mobilization, we must put pressure on political parties and boards so they stop appealing to the false obligation to respect the Electoral Law, and we must ask them to respect professional criteria applied to political information when there are no campaigns. If there were still political representatives in any media that threaten pluralism and the neutrality proclaimed in the laws, the solution 
would not be to ask for "equal" distribution of the cake, eroding the professionalism of those providing information, but instead to ask for a legal reform that secured the degovernmentalization and the depolitization of these media. We are following the path of new regulations for local public channels, as desired - and maybe soon to be achieved - by Catalan public media. We are hoping to finally have them approved soon.

However, in 2015, as coverage of the recent regional elections in Catalonia (27 September) and general Spanish elections (20 December) showed, electoral blocks continue. Different governments in Spain and Catalonia (leftist, nationalist...) have not suppressed the blocks, no matter what they have said in the past. Therefore, the conflict persists.

\section{Mediation by the institutions}

In accordance with its public function, the Broadcasting Council was very active as a mediator during the first years of the conflict. Preliminary meetings in 2006 between delegations from this Council and the CJA took place, and on 27 March they presented an agreement on Recommendations for the quality of information during electoral processes for the public providers of broadcasting communication services. The Council sought to overcome the rigidity of the electoral blocks and introduced a series of specific items to achieve consensus.

Some journalists criticized the "equality in steps" that was established, which called for respecting some time ranges agreed to by the boards. The hierarchy within the blocks would be ruled by newsworthiness criteria; duration and order could vary. The Council asked for journalistic professionalism to be respected, and that the criteria applied throughout the year also be valid during electoral campaigns.

The "parties' own TV transmissions" (in which parties provide images or footage themselves or include the most positive moments of filmed footage or live broadcasts) and free access to campaign activities are linked to "edited transmission" ("senyal editat" in Catalan), which is one of the most controversial issues concerning press freedom. As for equality of opportunities, the Council demanded that parties without parliamentary representation also be given a voice in order to overcome the difficulties faced by parties with no representation on the channels' boards. They pointed to the so-called French system, in which editors are responsible for the equality of the time allocated to both parliamentary and nonparliamentary voices.

The agreement reached on 7 March included references to the "signature strike". The Council recommended avoiding a repeat of this protest in the future because it would create suspicions about the quality of information on public media. The Council scolded journalists for paying more attention to the protest than to newsworthy events.

Again, as we see in the report on pluralism in the campaign for the home rule referendum, references to the so-called "signature strike" carried out by the journalists at Televisió de Catalunya have been longer than others, leaving out information on the electoral campaign. 
The Council disliked that the protest did not "correspond with the present reality or the pluralistic path of Catalan public media". It exhorted against a repeat of this specific protest formula that "discredits all political parties" and "does not meet the goal of encouraging participation for which public broadcasting services are responsible", and considered the protest to be demobilizing. It also highlighted the lack of airtime devoted to political debate and civic participation, which contributed to trivializing democratic politics.

Another institution, the Catalan Ombudsman (Síndic de Greuges de Catalunya), was also involved in this controversy in 2005. It issued a report stating that blocks damaged the right to information, and recommended that alternative formulas should be sought in order to apply professional standards to political coverage.

The protest continues because the blocks system has not been totally removed. Carles Prats, TV3 news editor, is leading the campaign against the blocks and the political control of the public media (by the Public Media Work Group of the CJA). He believes that blocks are "a democratic anomaly, a remarkable aberration that helps discredit journalism and politics, making democracy weaker. Prior censorship does not guarantee pluralism but is a symptom of democratic immaturity".

\section{Conclusions and discussion}

What has become evident in this conflict on the so-called electoral blocks, when analysed historically, is that the journalists in Catalan public media have protested in order to stop having information on the one hand and politically controlled advertisements on the other be equated with one another.

Professional associations have supported the journalists' protests, and the CJA has played a remarkable role. The arguments put forward by the CJA, the Journalists' Union, the professionals themselves, as well as the Catalan Ombudsman, all have points in common.

The Broadcasting Council has been the institution most broadly involved in supervising pluralism and making the effort to mediate the issue with journalists. Its work has been praiseworthy, but the rationales of the boards, public institutions and some journalists in management positions are closer to those of political parties, which so far have not changed the blocks. The Catalan Broadcasting Council and the electoral boards themselves reproduce the seat distribution in the Catalan Parliament quite closely. The consensus achieved by these institutions should be respected, and the public media should be seen as a common ground instead of a stage to fight for the quota.

Political parties are the institutions least involved in overcoming the blocks, even when they are not totally opposed to loosening them. Both socialist and conservative parties have submitted appeals to the electoral boards. The smallest political forces have seen how a time range also benefitted them, because it allowed them to get no less coverage than half the attention received by big political parties. Equalizing parties' advertisements and campaign reports with quotas applies partisan norms to electoral information by constricting the participation spectrum to parliamentary representation.

Considering the theoretical approach to journalism's raison d'être, this parliamentary control negates journalistic self-regulation and takes the place of Bordens' civic functions of the media. It also breaches journalism's responsibilities of observation, evaluation, interpretation and balance. 
The global influence of parties on media bias is, in this case, directly dictated by the parties' spin-doctors. The parties modify the scenario in film footage and live broadcasts or when selecting images for the electoral block.

The mutual mistrust demonstrated for so many years (reflected in professional protests, electoral laws and political parties' appeals) may increase citizens' mistrust of the media and politics, as many cited studies show (Berganza, Herrero and Carratalà 2016). The lack of dialogue between the political parties and public media journalists could harm them both, as statistics and research in different countries have shown (Pfetsch, Maurer, Mayerhöffer and Moring 2014, Esser and Pfetsch 2016).

Indeed, those who point out that some conflict between politicians and journalists is needed in order to maintain a vibrant public sphere where journalists act as watchdogs and are not too close to power, do not support blocks. In this regard, the leader of the CJA's campaign against the blocks, the news editor Carles Prats, advocates for a tension that avoids docile journalism when facing political power.

It remains unclear whether or not these blocks have any positive impact on electoral participation or even on audiences. In addition, other means of influencing voting, such as blogs and social media, cannot be controlled. Only the public broadcasting channels are subjected to that kind of suspicion, in an unbalanced situation that does not consider press freedom to be the same for different types of ownership.

Whether or not it is accepted that the struggle between journalism and politicians increases cynicism, a second decade of conflict has started. Such an ingrained conflict depicts a negative relationship between journalists and political representatives and clearly shows how difficult it is to avoid mutual mistrust.

In 2007, a study about political disaffection in Catalonia included a proposal to establish a moratorium on electoral blocks in order to better negotiate how to eliminate them and control transparency and pluralism in electoral periods (Vallès 2008). This advice was not followed.

In the electoral campaign information system, trust would involve giving freedom to editors to organize the order and duration of news pieces; it would also mean trusting in pluralism to control institutions, which provide information on and oversee adherence to pluralistic information coverage. The Catalan Broadcasting Council report on pluralism in the 2016 General Election coverage in Catalonia found that TV3, which was not organized by blocks at the time, had the most balanced presence of political parties and representatives (CAC 2016: 245). This fact could be a starting point for the conflict to come to an end.

\section{Notes}

${ }^{1}$ The broadcasting channels were: Televisió de Catalunya, Catalunya Ràdio, Barcelona Televisió and Badalona Comunicació.

${ }^{2}$ National general election to choose Spanish Parliament representatives.

${ }^{3}$ The announcement took place at the Second Symposium on Press Freedom in Lleida (Catalonia, Spain). Available at

http://www.periodistes.org/ca/noticia/segona-edicio-del-simposi-sobre-llibertat-depremsa-3-i-4-de-maig-a-lleida-1992.html 
${ }^{4}$ In February 2017, the public Spanish Television workers ran a protest against the political control in the channel.

${ }^{5}$ Electoral campaigns in Spain last fifteen days and include news pieces in public media.

${ }^{6}$ Protests have been documented in the following elections:

06/11/2003 Catalan Parliament elections coverage

14/03/2004 Spanish Parliament

18/06/2006 Referendum on Catalan home rule

01/11/2006 Catalan Parliament

27/05/2007 Local governments and General Council of Aran (subregion of

Catalonia with its own language)

${ }^{7}$ The list of documents is annexed to the final references and concern the following institutions:

Consell de l'Audiovisual de Catalunya (Catalan Broadcasting Council, a regulatory authority)

Col-legi de Periodistes de Catalunya (Catalan Journalists' Association, in this article, CJA)

Sindicat de Periodistes (Journalists' Union)

Síndic de Greuges (Catalan Ombudsman)

Junta Electoral Provincial de Barcelona (Barcelona Electoral Board)

Junta Electoral Central (Spanish Electoral Board)

${ }^{8}$ The representatives interviewed were:

Rafael Jorba (member of the Catalan Broadcasting Council)

Josep Carles Rius (head of the CJA)

Pilar Antillach (TV3 journalist and member of the CJA)

Rosa Marqueta (TV3 news editor)

Manel Raya (TV3 news editor)

Ferran Requejo (member of the Barcelona Electoral Board)

Sofía Gandarias (Spanish Electoral Board secretary)

Manuel Delgado (delegate to the Spanish Electoral Board)

Carles Prats (TV3 news editor and member of the CJA, leader of the campaign

against electoral quotas and political control over the media)

${ }^{9}$ All the documents and journalists' quotations have been translated by the author.

${ }^{10}$ Spanish, Catalan and local broadcasting channels, including television and radio.

${ }^{11}$ The TV3 news shows analysed are TN Migdia (noon TV news bulletin), TN

Vespre (evening TV news bulletin) and La nit al dia (late-night TV news bulletin).

${ }^{12}$ On 11 March 2004, a terrorist attack took place on Madrid local trains similar to the attacks on 9/11/2001 in New York.

\section{References}

Almiron, N., Capurro, M. and Santcovsky, P. (2010a) Los bloques electorales en los medios públicos del Estado español: una excepción en Europa. Quaderns del CAC, 34, 13(1), pp. 95-102.

Almiron, N., Capurro, M. and Santcovsky, P. (2010b) The Regulation of Public Broadcasters' News Coverage of Political Actors in Ten European Union Countries. Comunicación y Sociedad, 23(1), pp. 205-236. 
Ansolabehere, S. and Iyengar, S. (1995) Going negative: how political advertisements shrink and polarize the electorate. New York: Free Press.

Ariely, G. (2015) Does Commercialized Political Coverage Undermine Political Trust? Evidence Across European Countries. Journal of Broadcasting and Electronic Media, 59(3), pp. 438-455. http://dx.doi.org/10.1080/08838151. 2015.1055000

Baum, M. and Groeling, T. (2009) Shot by the messenger: partisan cues and public opinion regarding national security and war. Political Behaviour, 31, pp.157-186. http://dx.doi.org/10.1007/s11109-008-9074-9

Bennet, S. E., Rhine, S., Flickinger, R. and Bennet, L. (1999) Video Malaise Revisited: Public Trust in the Media and Governemnt. The Harvard International Journal of Press Politics, 4(4), pp. 8-23. https://doi.org/10.1177/ 1081180X9900400402

Berganza, R., Herrero, B. and Carratalà, A. (2016) Distrust of Spanish journalists in public institutions based on the study of organizational factors. Disertaciones, 9(1). Retrieved February 01, 2017 from http://revistas.urosario.edu.co/ index.php/disertaciones

Bermúdez, N. A. (2012) Effects of social media on individual voting (Doctoral dissertation, Gonzaga University). Washington: Department of Communication and Leadership, Gonzaga University.

Borden, S. L. (2007) Journalism as practice. Macintyre, virtue ethics and the press. Michigan: Ashgate Publishing.

Brants, K., De Vreese, C. H., Möller, J. and Van Praag, P. (2010) The Real Spiral of Cynicism? Symbiosis and Mistrust between Politicians and Journalists. International Journal of Press/Politics, 15(1), pp. 25-40. http://dx.doi.org/10.1177/1940161209351005

CAC/Catalan Broadcasting Council (2016) Informe específic de pluralisme a la televisió i a la ràdio durant la campanya de les eleccions generals 2016. Retrieved February 01, 2017, from http://www.cac.cat/pfw_files/cma/ actuacions/2016_INFORME_ELECCIONS_GENERALS.pdf

Carrillo, N. (2012) El xou nostrat. L'infoentreteniment en el contingut i la recepció del periodisme electoral a Catalunya (eleccions de 2008 i 2010) (Doctoral dissertation, Autonomous University of Barcelona). Bellaterra: UAB.

Carrillo, N. and Ferré-Pavia, C. (2013) Infotainment in news reports: the case of the 2010 Catalan elections. Catalan Journal of Communication and Cultural Studies, 5(1), pp. 3-17. http://dx.doi.org/10.1386/cjcs.5.1.3_1

Ceron, A. (2015) Internet, News, and Political Trust: The Difference Between Social Media and Online Media Outlets. Journal of Computer-Mediated Communication, 20, pp. 487-503. http://dx.doi.org/10.1111/jcc4.12129

Chanley, V., Rudolph, T. and Rhan, W. (2000) The Origin and Consequences of Public Trust in Government. Public Opinion Quaterly, 64(3), pp. 239-256. https://doi.org/10.1086/317987

Cohen, N. (2014) The Broken Table: The Detroit Newspaper Strike and the State of American Labor. Labour, 74, pp. 377-379.

Commission on Freedom of the Press (1947) A free and responsible press. Chicago: University of Chicago Press.

Cooper, T. (Ed.). (1989) Communications ethics and global change. New York: Longman. 
Cooper, T. and College, E. (1990) Comparative International Media Ethics. Journal of Mass Media Ethics, 5(1), pp. 3-14. https://doi.org/10.1207/s15327728 jmme0501_1

Demers, F. (2006) The Fundamental Role Played by Unionism in the SelfStructuring of Professional Journalists from Québec. Canadian Journal of Communication, 31(3), pp. 659-674. https://doi.org/10.22230/cjc.2006v31n $3 \mathrm{a} 1839$

De Vreese, C. H. (2005) The spiral of cynicism reconsidered. European Journal of Communication, 20, pp. 283-301. http://dx.doi.org/10.1177/0267323105055259

De Vreese, C. H. and Elenbaas, M. (2008) Media in the game of politics: Effects of strategic metacoverage on political cynicism. International Journal of Press Politics, 13, pp. 285-309. http://dx.doi.org/10.1177/1940161208319650

EFE-Eldiario.es (2015) El Tribunal de Estrasburgo rechaza una denuncia contra los bloques electorales. Retrieved November 03, 2015, from http://www.eldiario.es/cultura/Tribunal-Estrasburgo-rechaza-denuncia electorales_0_409809552.html

Elenbaas, M. and De Vreese, C. H. (2008) The effects of strategic news on political cynicism and vote choice among young voters. Journal of Communication, 58, pp. 550-567. http://dx.doi.org/10.1111/j.1460-2466.2008.00399.x

Esser, F. and Pfetsch, B. (2016) Comparing Political Communication: An Update. Working paper, 89. Zurich and Berlin: National Centre of Competence in Research (NCCR).

Ferré-Pavia, C. (Ed.) (2013) Infoentretenimiento. El formato imparable de la era del espectáculo. Barcelona: Editorial UOC.

Ferré-Pavia, C. (Ed.) (2014) El uso de las redes sociales. Ciudadanía, política y comunicación. Bellaterra: Communication Institute-InCom UAB.

Ferrer, L. (2007) Blocs electorals? Sí, gràcies. Retrieved September 09, 2015, from http://v60news.blogspot.com/2007/05/blocs-electorals-s-grcies

García Mahamut, R. and Rallo Lombarte, A. (2013) Neutralidad y pluralismo de los medios de comunicación en las campañas electorales. La reforma de la LOREG en 2011. Revista Española de Derecho Constitucional, 98, pp. 201-240.

Gnisci, A., Van Dalen, A. and Di Conza, A. (2014) Interviews in a Polarized Television Market: The Anglo-American Watchdog Model Put to the Test. Political Communication, 31, pp. 112-130. http://dx.doi.org/10.1080/ 10584609.2012.747190

Grabe, M. E. and Bucy, E. P. (2009) Image Bite Politics: News and the Visual Framing of Elections. Oxford: Oxford University Press. https://doi.org/10.1093/ acprof:oso/9780195372076.001.0001

Greenland, K. (2013) Negotiating Self-presentation, Identity, Ethics, Readership and Privacy in the LIS Blogosphere: A Review of the Literature. Australian Academic and Research Libraries, 44(4), pp. 217-225. http://dx.doi.org/ 10.1080/00048623.2013.843236

Groeling, T. (2013) Media Bias by the Numbers: Challenges and Opportunities in the Empirical Study of Partisan News. Annual Review of Political Science, 16, pp. 129-151. http://dx.doi.org/10.1146/annurev-polisci-040811-115123

Gross, K., Aday, S. and Brewer, P. (2004). A Panel Study of Media Effects on Political and Social Trust after September 11, 2001. The Harvard International 
Journal of Press Politics, 9(4), pp. 497-3. http://dx.doi.org/10.1177/ $1081180 X 04269138$

Hehman, E., Graber, E. C., Hoffman, L. H. and Gaertner, S. L. (2012) Warmth and competence: a content analysis of photographs depicting American presidents. Psychology of Popular Media Culture, 1, pp. 46-52. http://dx.doi.org/10.1037/a0026513

Henderson, J. (2013) Searching for Ethics in Social Media. Journal of Mass Media Ethics, 28(3), pp. 217-219. http://dx.doi.org/10.1080/08900523.2013.805570

Hsin-Hsuan, L., Van Dolen, W. and Kolk, A. (2013) On the Role of Social Media in the 'Responsible' Food Business: Blogger Buzz on Health and Obesity. Journal of Business Ethics, 118(4), pp. 695-707. https://doi.org/10.1007/s10551-0131955-0

Jeffres, L., Atkin, D. and Neuendorf, K. (2002) A Model Linking Community Activity and Communication with Political Attitudes and Involvement in Neighbourhoods. Political Communication, 19, pp. 387-421. https://doi.org/10.1080/01957470290055574

Khaquli, I. and Esipisu, M. (2009) Eyes of Democracy: The Media and Elections. London: Commonwealth Secretariat.

Kleinnijenshuis, J., Van Hoof, A. and Oegema, D. (2006) Negative News and the Sleeper Effect or Distrust. The Harvard International Journal of Press Politics, 11(2), pp. 86-104. https://doi.org/10.1177/1081180X06286417

Kleppinger, H. (2000) The Declining Image of the German Political Elite. The Harvard International Journal of Press Politics, 5(4), pp. 71-80. https://doi.org/10.1177/1081180X00005004005

Lambeth, E. (1986) Committed journalism. An ethics for the profession. Bloomington, IN: University of Indiana Press.

Lee, T. T. (2005) The Liberal Media Myth Revisited: An Examination of Factors Influencing Perceptions of Media Bias. Journal of Broadcasting and Electronic Media, 49(1), pp. 43-64. http://dx.doi.org/10.1207/s15506878jobem4901_4

Lowry, D. T. (2008) Network TV news framing of good vs. bad economic news under Democrat and Republican presidents: a lexical analysis of political bias. Journalism Mass Communication Quarterly, 85, pp. 483-498. http://dx.doi.org/10.1177/107769900808500301

Merrill, J. C. (1989) The dialectic in journalism: Toward responsible use of press freedom. Baton Rouge-London: Lousiana State University Press.

Min, Y. (2004) News Coverage of Negative Political Campaigns. An Experimental of Negative Campaigns Effects on Turnout and Candidate Preference. The Harvard International Journal of Press Politics, 9(4), pp. 95-111. https://doi.org/10.1177/1081180X04271861

Montero Vargas, D. (2015) Pluralismo informativo y televisión en campañas electorales en España 2011-2015 (Master degree work, Autonomous University of Barcelona). Bellaterra: UAB.

Moy, P., McCoy, K., Spratt, M. and McCluskey, M. R. (2003) Media effects in public opinion about a newspaper strike. Journalism and Mass Communication Quarterly, 80(2), pp. 391-409. http://dx.doi.org/10.1177/107769900308000210

Neilson, T. (2012) Journalists Strike Online: Visibility, Field and 'The Huffington Post'. Global Media Journal, 20(12), pp. 1-10. 
Pew Research Center (2011) Press Widely Criticized, But Trusted More than Other Information Sources Views of the News Media: 1985-2011. Retrieved February 22, 2016, from http://www.people-press.org/2011/09/22/press-widelycriticized-but-trusted-more-than-other-institutions/

Pfetsch, B., Maurer, P., Mayerhöffer, E. and Moring, T. (2014) A Hedge between Keeps Friendship Green-Concurrence and Conflict between Politicians and Journalists in Nine European Democracies In Comparing Political Communication across Time and Space. New Studies in an Emerging Field, eds. Canel, M. J. and Voltmer, K., pp. 172-191. New York: Springer.

Planas, M./Ara (2016) Què ha passat amb els blocs electorals a TV3? Retrieved June 15, 2016, from www.ara.cat/eleccions26j/Que-passat-blocs-electoralsTV3_0_1595840466.html

Porto, M. (2007) TV News and Political Change in Brazil: The Impact of Democratization on TV Globo's Journalism. Journalism, 8(4), pp. 381-402. http://dx.doi.org/10.1177/1464884907078656

Ramsden, G. (1996) Media Coverage of Issues and Candidates: What Balance is Appropriate in a Democracy? Political Science Quarterly, 111(1), pp. 65-81. https://doi.org/10.2307/2151928

Rawnsley, G. and Gong, Q. (2011) Political Communications in Democratic Taiwan: The Relationship between Politicians and Journalists. Political Communication, 28(3), pp. 323-340. http://dx.doi.org/10.1080/10584609.2011. 572462

Rodríguez, R., Figueras, M., Mauri, M. And Alsius, S. (2013) How Dominant are Official Sources in Shaping Political News Coverage in Spain? The Perceptions of Journalists and Citizens. Journal of Mass Media Ethics, 28, pp. 103-118. https://doi.org/10.1080/08900523.2013.792697

Schuck, A. R., Boomgaarden, H. G. and De Vreese, C. H. (2013) Cynics all around? The impact of election news on political cynicism in comparative perspective. Journal of Communication, 63, pp. 287-311. http://dx.doi.org/10.1111/jcom. 12023

Shah, D. (1998) Civic Engagement, Interpersonal Trust and Television Use: An Individual-Level Assessment of Social Capital. Political Psychology, 19(3), pp. 469-496. https://doi.org/10.1111/0162-895X.00114

Shehata, A. (2014) Game frames, issue frames, and mobilization: Disentangling the effects of frame exposure and motivated news attention on political cynicism and engagement. International Journal of Public Opinion Research, 26, pp. 157177. http://dx.doi.org/10.1093/ijpor/edt034

Terribas, M. (2004) La desaparició del periodisme: senyal realitzat i blocs electorals. Comunicació 21,4 , pp. 78-79.

Tomàs, X. (2007) Per a què serveixen els blocs electorals en campanya? Retrieved November 11, 2007, from http://xtomas.bloc.cat/post/2918/

Uslaner, E. (1998) Social Capital, Television and the 'Mean World': Trust, Optimism and Civic Participation. Political Psychology, 19(3), pp. 441-467. https://doi.org/10.1111/0162-895X.00113

Uslaner, E. (1999) Trust but Verify: Social Capital and Moral Behavior. Social Science Information, 38, pp. 29-55. https://doi.org/10.1177/05390189903800 1002 
Vallès, J. M. (Ed.) (2008) Actituds polítiques i comportament electoral a Catalunya. Retrieved May 06, 2008, from http://exteriors.gencat.cat/web/.content/ 00_AMBITS/governobert/participacio/publicacions/guies_recerca/1_ActitudsP olitiques-i-comportament-electoral-a-Catalunya_2008.pdf

Van Dalen, A., Albæk, E. and De Vreese, C. H. (2011) Suspicious minds: Explaining political cynicism among political journalists in Europe. European Journal of Communication, 26(2), pp. 147-162. http://dx.doi.org/10.1177/0267323111 404841

Zabaleta, I. (2000) Politics and television news in Spain In Contemporary Spanish Cultural Studies, eds. Jordan, B. and Morgan-Tamosunas, R., pp. 159-169. London: Edward Arnold Publishers, New York: Oxford University Press.

\section{Documents referred to and analysed}

Col-legi de Periodistes de Catalunya (1999) Per un nou model de ràdio i televisió pública.

Col-legi de Periodistes de Catalunya (2003) Per la reforma dels mitjans de comunicació públics.

Col-legi de Periodistes de Catalunya, Asociación de la Prensa de Madrid, Colexio de Xornalista de Galicia (2007) Document that claims for respect to professional criteria in electoral campaigns.

Col-legi de Periodistes de Catalunya (2008) Manifest en defensa d'uns mitjans públics independents.

Col-legi de Periodistes de Catalunya/Mir, J.; Pareja, C.; Segura, G. (2007) Dictamen sobre el dret a la informació i els blocs d'informació electoral als mitjans públics.

Comitè Professional de Catalunya Ràdio i Comitè Professional de TVC (2005) Document that claims for the depolitization of Catalan Broadcasting Media System.

Consell de l'Audiovisual de Catalunya (2006) Informes específics sobre el pluralisme a la ràdio i la televisió en el referèndum de l'Estatut i les eleccions al Parlament.

Consell de l'Audiovisual de Catalunya (2007) Informe especific de pluralisme durant la campanya de les eleccions municipals 2007.

Consell de l'Audiovisual de Catalunya (2007) Recomanacions sobre la qualitat de la informació en els processos electorals per als prestadors públics de serveis de comunicació audiovisual.

Junta Electoral Central (2006) Recurs del PSC contra acord de la JEP sobre criteris de la CCRTV a les eleccions de l'Estatut d'autonomia 2006.

Junta Electoral Provincial (2007) Recurs de CiU contra acords de la CCRTV sobre criteris de les eleccions municipals 2007.

Sindicat de Periodistes de Catalunya (2006) Document sobre blocs electorals i la nova llei de CCRTV.

Sindicat de Periodistes de Catalunya (2007) Balanç de la mobilització contra els blocs electorals. 